\title{
Adjuvants to improve aerial control of the citrus mealybug Planococcus citri (Hemiptera: Pseudococcidae) using entomopathogenic nematodes
}

\author{
S. van Niekerk and A.P. Malan* \\ Department of Conservation Ecology and Entomology, Faculty of \\ AgriSciences, Stellenbosch University, Private Bag X1, Matieland 7602, \\ South Africa
}

(Received 26 March 2013; Accepted 10 October 2013)

\begin{abstract}
The citrus mealybug, Planococcus citri, is a highly destructive pest of citrus, occurring only in the aerial parts of plants. Humidity will be one of the key factors to consider when using entomopathogenic nematodes (EPN) as biological control agents. Different adjuvants can be added to suspensions of EPNs, to improve control as a foliar application. An aqueous suspension containing Heterorhabditis zealandica and $0.3 \%$ Zeba ${ }^{\circledR}$ significantly increased P. citri mortality by $22 \%$ at $80 \%$ relative humidity $(\mathrm{RH})$ with a temperature cycle starting at $22^{\circ} \mathrm{C}$ for $14 \mathrm{~h}$ and $11^{\circ} \mathrm{C}$ for $11 \mathrm{~h}$. The same polymer formulation was tested for Steinernema yirgalemense and mortality of P. citri increased by $21 \%$ at $60 \% \mathrm{RH}$ and by $27 \%$ at $80 \% \mathrm{RH}$. The addition of Nu-Film-P ${ }^{\circledR}$ and Zeba ${ }^{\circledR}$ to $H$. zealandica suspensions did not significantly retard application run-off on citrus leaves. The combination of Nu-Film- $\mathrm{P}^{\circledR}$ and Zeba ${ }^{\circledR}$, however, was able to significantly retard sedimentation, increasing the average number of nematodes deposited on $2-\mathrm{cm}^{2}$ leaf discs by 10 nematodes. In an aqueous suspension, nematodes settle rapidly to the bottom, resulting in an uneven distribution of nematodes. Xanthan gum, at a concentration of $0.2 \%$, was highly effective at retarding sedimentation, with $72 \%$ of the initial nematode number still in suspension after $1 \mathrm{~h}$. Zeba ${ }^{\circledR}$, at a concentration of $0.3 \%$, despite not being as effective as Xanthan gum, nevertheless still retarded sedimentation significantly. This is the first report of the potential of Nu-Film- ${ }^{\circledR}$ and Zeba ${ }^{\circledR}$ to improve EPN performance against $P$. citri when used above ground in citrus orchards.
\end{abstract}

\section{Introduction}

Planococcus citri (Risso) (Hemiptera: Pseudococcidae), the citrus mealybug, is globally distributed and has been reported as a serious pest of citrus in Africa (Hattingh \& Tate, 1996; Hattingh et al., 1998; Wakgari \& Giliomee, 2003), Australia (Smith et al., 1997; Gullan, 2000), the Mediterranean Basin (Blumberg et al., 1995; Franco et al., 2004), as well as North, Central and South America

*E-mail: apm@sun.ac.za
(Bartlett \& Lloyed, 1958). Planococcus citri is able to reproduce rapidly under optimal environmental conditions, potentially infesting up to $100 \%$ of fruit, even when spring populations could hardly be detected (Hattingh \& Moore, 2003). Mealybugs, in general, are difficult to control chemically, as they display cryptic behaviour, are covered with protective waxes (Michelakis \& Hamid, 1995; Franco et al., 2004), and have been reported to develop resistance to insecticides (Blumberg \& Van Driesche, 2001; Mahfoudhi \& Dhouibi, 2009). The use of chemical control is also undesirable, because insecticides disrupt natural enemy populations 
(Hattingh, 1993; Hattingh \& Tate, 1995, 1996; Hattingh et al., 1998; Hattingh \& Moore, 2003) and have detrimental effects on the environment.

Entomopathogenic nematodes (EPNs) are used as biological control agents for a wide range of economically important insect pests (Grewal et al., 2005) and could be an alternative to the chemical control of $P$. citri. The nematodes have an active host-seeking ability, which enables them to reach hosts in cryptic habitats (Gaugler \& Boush, 1979). However, as above-ground conditions are not optimal for nematode survival (Mráček, 2002; Tomalak et al., 2005), successful control of mealybugs on citrus using EPN is extremely challenging. Abiotic factors, including temperature (Lacey et al., 2005), ultraviolet radiation (Gaugler \& Boush, 1978; Gaugler et al., 1992), wind and ambient humidity (Unruh \& Lacey, 2001), individually and combined, can limit the efficacy of EPNs as biological control agents when used above ground.

Desiccation, which is accelerated by low humidity levels and high wind speed, is the most limiting abiotic factor, as nematodes require a water film to maintain mobility and ensure survival (Wright et al., 2005). Schroer et al. (2005) evaluated whether various surfactantpolymer formulations improved the ability of Steinernema carpocapsae (Weiser 1955) Wouts, Mráček, Gerdin \& Bedding, 1982 to control the diamondback moth, Plutella xylostella (Linnaeus) (Lepidoptera: Plutellidae) on cabbage leaves at above-ground conditions. A formulation containing $0.3 \%$ Rimulgan $^{\circledR}$ (a surfactant) and $0.3 \%$ of the polymer xanthan (an antidesiccant) obtained the best control, causing $>90 \%$ diamondback moth mortality at $80 \%$ relative humidity $(\mathrm{RH})$ and $>70 \%$ mortality at $60 \%$ RH. Schroer \& Ehlers (2005) tested the same formulation for the control of diamondback moth on cabbage leaf bioassays under suboptimal conditions for nematode survival. Their results showed that the survival time of S. carpocapsae applied with the formulation was $22 \mathrm{~h}$ longer at $80 \% \mathrm{RH}$ and $17 \mathrm{~h}$ longer at $60 \% \mathrm{RH}$ than when the nematodes were applied with water only.

Van Niekerk \& Malan (2012) screened six local South African EPN species for virulence against P. citri and found both Steinernema yirgalemense Tesfamariam, Gozel, Gaugler \& Adams, 2005 and Heterorhabditis zealandica Poinar, 1990 to be highly effective at a concentration of 50 infective juveniles (IJ) per insect. They found, in a water activity bioassay, that $S$. yirgalemense was two times more tolerant to lower levels of free water and that this species was also able locate and infect $P$. citri faster than H. zealandica.

The objective of the present study was to evaluate the effect of adding adjuvants to aqueous suspensions of two nematode species. The effect on P. citri mortality and EPN deposition on citrus leaves was investigated, as well as the effect of two polymers on the sedimentation of nematodes in aqueous suspensions.

\section{Materials and methods}

Source of nematodes and insects

Experiments were conducted using H. zealandica (SF41; EU699436) originally isolated from soil collected in
Baviaanskloof near Patensie, Eastern Cape, South Africa (Malan et al., 2006) and S. yirgalemense (157-C; EU625295), originally isolated from soil collected from a citrus orchard near Friedenheim, Mpumalanga, South Africa (Malan et al., 2011). IJs were cultured according to the procedures described by Kaya \& Stock (1997) using Tenebrio molitor (Linnaeus) (Coleoptera: Tenebrionidae) larvae, at room temperature. Nematodes were harvested within the first week of emergence and stored in $150 \mathrm{ml}$ distilled water in $500-\mathrm{ml}$ vented culture flasks. The flasks were stored horizontally at $14^{\circ} \mathrm{C}$ and shaken weekly to improve aeration. IJs were used for experiments within the first 3 weeks after harvest. Concentrations used in experiments were quantified by using the method developed by Navon \& Ascher (2000). Mealybugs were cultured on butternuts. The identity of $P$. citri used in this study was verified using morphological (Wakgari \& Giliomee, 2005) and molecular techniques (Pieterse et al., 2010).

\section{Effect of two polymers on P. citri mortality}

Bioassays were conducted using multiwell bioassay plates (24 wells, flat bottom, Nunc ${ }^{\mathrm{TM}}$ Cat. No.144530, Sigma-Aldrich Pty. Ltd, Johannesburg, South Africa). Polymer products, Zeba ${ }^{\circledR}$ [starch-g-poly (2-propenamideco-2-propenoic acid) potassium salt, Tongaat Hulett Starch, Germiston, South Africa] and Xanthan gum [polysaccharide $\left(\mathrm{C}_{35} \mathrm{H}_{49} \mathrm{O}_{29}\right)$ ], were added to nematode suspensions containing either $H$. zealandica or S. yirgalemense, and mealybug mortality was determined at $60 \%$ and $80 \%$ RH. Five treatment plates and five control plates, each containing ten evenly distributed adult female mealybugs $(n=50)$ were prepared for each treatment. Each well was lined with a circular paper disc $(3 \mathrm{~mm}$ diameter) before mealybugs were added. Mealybugs were then inoculated individually with $50 \mu \mathrm{l}$ containing either $H$. zealandica or $S$. yirgalemense at a concentration of 80 IJs/insect for each of three treatments; Zeba ${ }^{\circledR}$ at a concentration of $3 \mathrm{~g} / 1$; Xanthan gum at a concentration of $2 \mathrm{~g} / \mathrm{l}$; and distilled water. Each treatment received its own control, in which mealybugs were treated with $50 \mu$ l of the treatment formulation containing no nematodes. Multiwell plates were covered with fine netting, which allowed airflow while preventing mealybugs from escaping. To achieve the required $\mathrm{RH}$, airtight containers with solutions of glycerol $(60 \% \mathrm{RH})$ and $\mathrm{KNO}_{3}(80 \% \mathrm{RH})$ were prepared (Winston \& Bates, 1960). After treatment, plates with mealybugs were placed in humidity chambers and kept in a growth chamber with a day cycle starting at $22^{\circ} \mathrm{C}$ for $14 \mathrm{~h}$ and $11^{\circ} \mathrm{C}$ for $11 \mathrm{~h}$. Mealybug mortality was determined after $72 \mathrm{~h}$. The experiment was repeated on a separate date.

\section{Effect of adjuvants on nematode deposition and sedimentation}

Heterorhabditis zealandica suspensions containing: (1) nematodes in water only; (2) Nu-Film- $\mathrm{P}^{\circledR}$ (poly-1p-menthene, spreader, sticker; Hydrotech, Pretoria, South Africa) at a concentration of $0.6 \mathrm{ml} / 1$ + nematodes; (3) Zeba ${ }^{\circledR}$ at a concentration of $3 \mathrm{~g} / 1+$ nematodes; and (4) Nu-Film-P ${ }^{\circledR}+$ Zeba ${ }^{\circledR}+$ nematodes were applied to citrus trees at the Welgevallen experimental farm, Stellenbosch, Western Cape. Each treatment was applied to randomly selected leaves on individual trees, with a spacing of two 


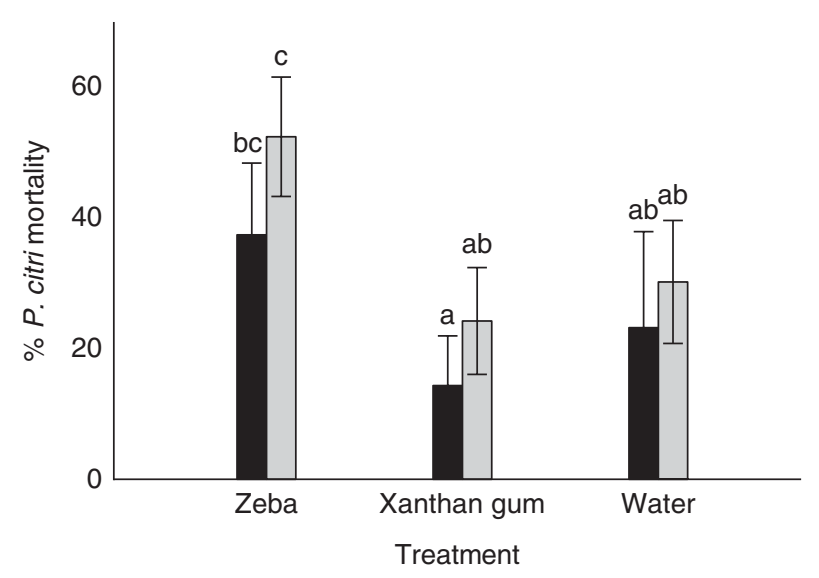

Fig. 1. Percentage mortality (95\% confidence interval) of Planococcus citri after exposure to 80 infective juveniles per insect of Heterorhabditis zealandica in a suspension of Zeba ${ }^{\circledR}$, Xanthan gum or water only at $60 \%$ (black bars) and $80 \%$ (grey bars) relative humidity (two-way ANOVA $\left(F_{(2,54)}=0.38 ; P=0.67\right)$ ). Different

letters above vertical bars indicate significant differences.

untreated trees between the treated trees. Nematodes were applied at a concentration of $1000 \mathrm{IJs} / \mathrm{ml}$ with the aid of calibrated hand-held spray applicators. Leaves were left for $3 \mathrm{~min}$ to allow excess fluid to run off before randomly selected leaves were removed from the application area. Two $2-\mathrm{cm}^{2}$ discs were cut out from each of the five leaves for each treatment tested $(n=10)$. Each leaf disc was individually rinsed off in $5 \mathrm{ml}$ tap water, and the number of nematodes present in each suspension was documented. The experiment was repeated on a separate date. The data of both experiments were pooled for analysis.

Zeba ${ }^{\circledR}$ and Xanthan gum were evaluated in terms of their ability to retard sedimentation of $H$. zealandica in a water suspension. Zeba ${ }^{\circledR}$, at a concentration of 0.1 , 0.2 or $0.3 \%$, and Xanthan gum, at a concentration of 0.1 or $0.2 \%$, were added to a nematode concentration of $1000 \mathrm{IJs} / \mathrm{ml}$. Both polymers were compared to a control that contained nematodes in water only. Treatments were added to $25-\mathrm{ml}$ measuring cylinders (of diameter $1.5 \mathrm{~cm}$ ) and stirred thoroughly to ensure that the nematodes were evenly distributed. To estimate sedimentation time, a $50 \mu \mathrm{l}$ sample of the suspension was collected from a depth of $2 \mathrm{~cm}$ after $0-, 3-, 10-, 20-, 30-$ and 60-min intervals from each of three cylinders prepared per treatment $(n=3)$ and the number of nematodes determined. The experiment was repeated on a separate date.

\section{Data analysis}

All statistical analyses were performed using STATISTICA 9.0 software (StatSoft Inc., Tulsa, Oklahoma, USA). Data were analysed using ANOVA, with post-hoc comparison of means using Bonferroni's method, or with a bootstrap multi-comparison if residuals were not normally distributed (Efron \& Tibshirani, 1993). Significant differences were determined on a $95 \%$ probability level. The data of control plates were used to prepare data of treatment plates with Abbott's formula before analysis, in order to compensate for mealybugs that died of causes other than nematode infection (Abbott, 1925). Nematode percentages for the effect of two polymers on nematode sedimentation were calculated as a percentage of the initial number of nematodes recorded directly after stirring had ceased.

\section{Results}

\section{Effect of two polymers on P. citri mortality}

Results of the effect of a suspension containing H. zealandica with $0.3 \% \mathrm{Zeba}^{\circledR}$ or $0.2 \%$ Xanthan gum on mealybug mortality at $60 \%$ and $80 \%$ RH showed no interaction between main effects humidity (two levels; $60 \%$ and $80 \% \mathrm{RH}$ ) and adjuvants (two levels; Zeba ${ }^{\circledR}$ and Xanthan gum) $\left(F_{(2,54)}=0.38 ; P=0.67\right)$. The concentration means differ from each other at each time point. The increase in mortality of $P$. citri with the addition of Zeba ${ }^{\circledR}$ was not significant at $60 \% \mathrm{RH}$ (fig. 1). The same formulation significantly increased mortality by $22 \pm 13 \%$ at $80 \%$ RH $(P=0.001)$. The Xanthan gum formulation performed worse than did the control (nematodes only), obtaining $14 \pm 3.5 \%$ mortality at $60 \%$ $\mathrm{RH}$ and $24 \pm 3.5 \%$ mortality at $80 \% \mathrm{RH}$, compared with the control which obtained $23 \pm 6.6 \%$ mortality at $\mathrm{RH}$ $60 \%$ and $30 \pm 4.11 \%$ mortality at RH $80 \%$. Data for both humidity levels were pooled together for further analysis using a one-way ANOVA $\left(F_{(2,57)}=15.27 ; \quad P<0.01\right)$, which confirmed that the Zeba ${ }^{\circledR}$ formulation obtained significantly higher mortality $(50 \pm 3.6 \%)$ than did either the Xanthan gum formulation $(19 \pm 2.7 \%)$ or the control $(27 \pm 3.8 \%)$.

Results of the effect of a suspension containing S. yirgalemense and $0.3 \% \mathrm{Zeba}{ }^{\circledR}$ or $0.2 \%$ Xanthan gum on mealybug mortality at $60 \%$ and $80 \%$ RH showed no interaction between main effects humidity (two levels; $60 \%$ and $80 \% \mathrm{RH}$ ) and adjuvants (two levels; Zeba ${ }^{\circledR}$ and Xanthan gum $)\left(F_{(2,54)}=0.22 ; P=0.30\right)$. The concentration

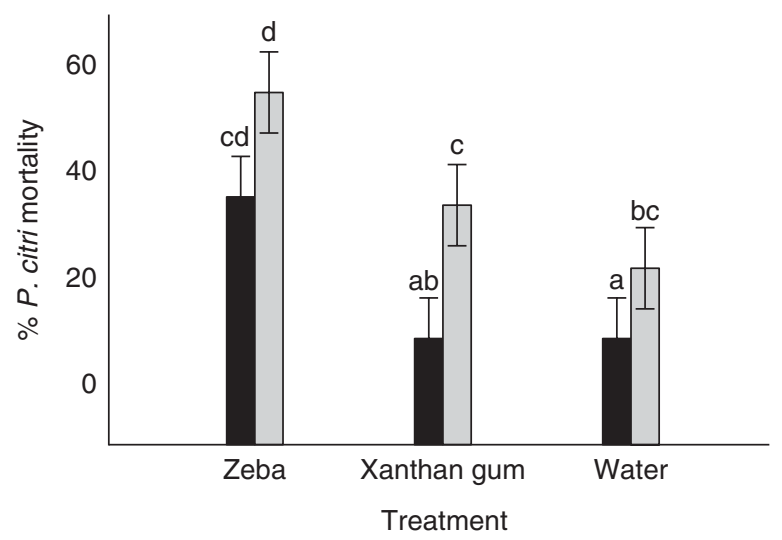

Fig. 2. Percentage mortality ( $95 \%$ confidence interval) of Planococcus citri after exposure to 80 infective juveniles per insect of Steinernema yirgalemense in a suspension of Zeba ${ }^{\circledR}$, Xanthan gum or water only at $60 \%$ (black bars) and $80 \%$ (grey bars) relative humidity $(\mathrm{RH})$ (two-way ANOVA $\left(F_{(2,54)}=0.22\right.$; $P=0.30)$ ). Different letters above vertical bars indicate significant differences. 


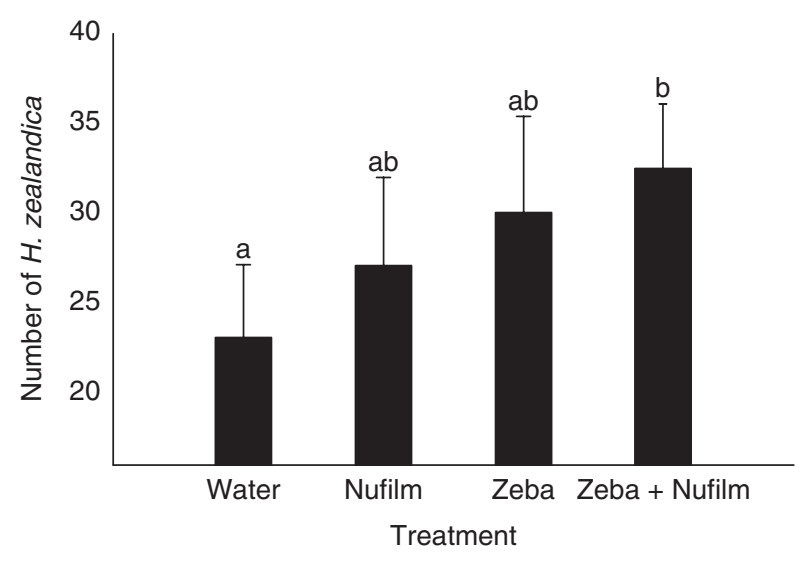

Fig. 3. Mean number ( $95 \%$ confidence interval) on $2-\mathrm{cm}^{2}$ discs of citrus leaf sprayed with a suspension containing Heterorhabditis zealandica infective juveniles with Nu-Film-P ${ }^{\circledR}, \mathrm{Zeba}^{\circledR}, \mathrm{Zeba}{ }^{\circledR}$ and Nu-Film-P ${ }^{\circledR}$, or water only (one-way ANOVA $\left(F_{(3,76)}=3.03\right.$;

$$
P<0.05) \text { ). }
$$

means differ from each other at each time point. The Zeba ${ }^{\circledR}$ formulation obtained significantly higher mortality of $36 \pm 3.8 \%$ at a $\mathrm{RH}$ of $60 \%$ and of $55 \pm 3.8 \%$ at $80 \%$ $\mathrm{RH}$ compared with the Xanthan gum formulation $(9 \pm 17 \%)$ mortality at $60 \% \mathrm{RH}$ and $34 \pm 2.2 \%$ mortality at $80 \% \mathrm{RH}$ and control formulation $(9 \pm 2.8 \%)$ mortality at $60 \% \mathrm{RH}$ and $22 \pm 4.11 \%$ mortality at $80 \% \mathrm{RH}$ (fig. 2 ). Data for both humidity levels were pooled for further analysis which confirmed that the Zeba ${ }^{\circledR}$ formulation obtained significantly higher mortality $(46 \pm 3.3 \%)$ than did either the Xanthan gum formulation (22 $\pm 4.0 \%$ mortality) or the control $(16 \pm 2.9 \%$ mortality $)$.

Data for all control plates used for Abbott's formula for corrected mortality were pooled to determine whether Zeba ${ }^{\circledR}$ or Xanthan gum had a toxic effect on mealybugs. Results showed no significant differences $\left(F_{(2,117)}=0.32\right.$; $P=0.72)$ for mortality of mealybugs treated with Zeba ${ }^{\circledR}$, Xanthan gum or water. Zeba ${ }^{\circledR}$ and Xanthan gum proved not to be toxic to mealybugs, as less than $2.5 \%$ mortality was obtained after mealybugs were treated with Zeba ${ }^{\circledR}$ or Xanthan gum, and did not obtain significantly higher mortality than was obtained with mealybugs treated with water only. Due to the poor performance of Xanthan gum, it was not evaluated further for improvement of nematode deposition on citrus leaves.

\section{Effect of adjuvants on nematode deposition and sedimentation}

Significant differences were obtained for numbers of $H$. zealandica present on leaf surfaces $\left(F_{(3,76)}=3.03\right.$; $P<0.05)$. The addition of Nu-Film- ${ }^{\circledR}$ and Zeba ${ }^{\circledR}$ to nematode application formulations did not significantly increase the average number of nematodes deposited on $2-\mathrm{cm}^{2}$ leaf discs. Only the combined formulation of Nu-Film-P ${ }^{\circledR}$ and Zeba ${ }^{\circledR}$ significantly increased the average number of nematodes deposited on leaf discs, with $10 \pm 1.1$ nematodes $(P=0.009)$ compared to the control. However, the increase observed was not significantly higher than that observed with the other two formulations tested (fig. 3).
Without the addition of a polymer, $91 \pm 6 \%$ of $H$. zealandica were recorded beyond a depth of $2 \mathrm{~cm}$ after $5 \mathrm{~min}$. A repeated measures ANOVA for Zeba ${ }^{\circledR}$ showed interaction between main effects concentration (four levels; 0, 0.1, 0.2 and $0.3 \%$ ) and time (five levels; $5,10,15,30$ and $60 \mathrm{~min})\left(F_{(12,80)}=28.36 ; P=0.001\right)$. The concentration means differ from each other at each time point. Compared to the control, none of the polymer concentration levels tested was able to retard sedimentation significantly $1 \mathrm{~h}$ after stirring had ceased. Only the $0.3 \%$ Zeba ${ }^{\circledR}$ formulation was able to retard sedimentation significantly $(P=0.001)$ after $30 \mathrm{~min}$ sedimentation, with $71 \pm 1.2 \%$ of the initial nematode number of 52 nematodes recorded (fig. 4).

A repeated measures ANOVA for Xanthan gum showed interaction between main effects concentration (three levels; $0,0.1$ and $0.2 \%$ ) and time (five levels; $5,10,15,30$ and $60 \mathrm{~min})\left(F_{(12,60)}=5.45 ; P=0.001\right)$. The concentration means differ from each other at each time point. Both Xanthan gum concentrations tested were able to retard $H$. zealandica sedimentation significantly at all the time intervals, compared to the control (fig. 5). No significant difference between the addition of 0.1 and $0.2 \%$ Xanthan gum was observed at any of the time intervals recorded. After 60 min sedimentation, 9, 54 and $72 \%$ of the initial nematode number were recorded for $0,0.1$ and $0.2 \%$ Xanthan gum, respectively.

\section{Discussion}

Planococcus citri is an important pest of citrus in South Africa, with the potential of infesting a high percentage of fruit under certain environmental conditions (Hattingh \& Moore, 2003). The addition of Xanthan gum to nematode suspensions caused no significant increase in $P$. citri mortality in any of the bioassays. No significant increase in mortality with the addition of Zeba ${ }^{\circledR}$ to $H$. zealandica

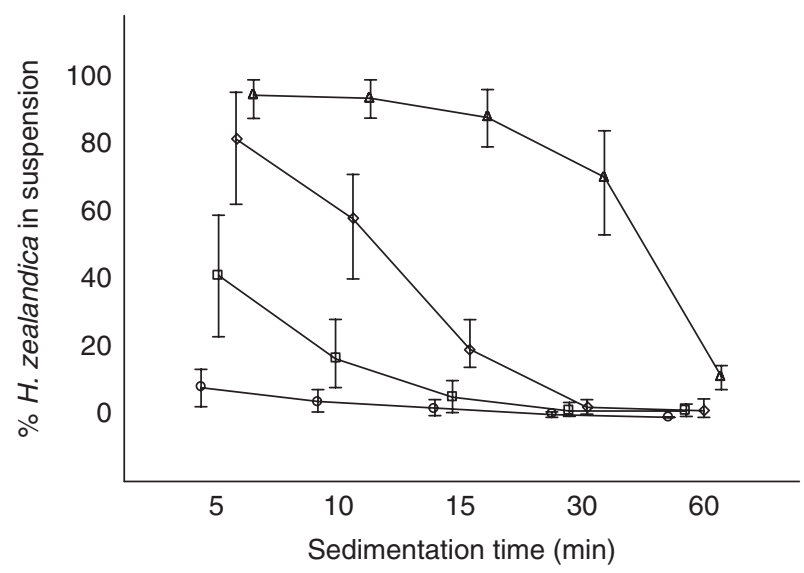

Fig. 4. Percentage infective juveniles of Heterorhabditis zealandica recorded at a depth of $2 \mathrm{~cm}$ after stirring (95\% confidence interval) at set time intervals for different concentrations $(O=0 \% ; \square=0.1 \% ; \diamond=0.2 \% ; \Delta=0.3 \%)$ of the polymer product Zeba ${ }^{\circledR}$ (repeated measures ANOVA $\left(F_{(12,80)}=28.36\right.$; $P=0.001)$ ). 


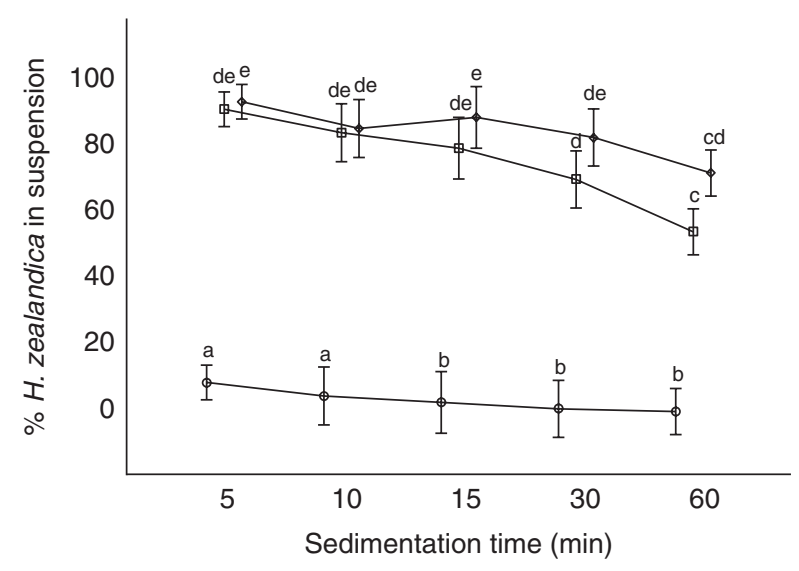

Fig. 5. Percentage infective juveniles of Heterorhabditis zealandica recorded at a depth of $2 \mathrm{~cm}$ after stirring (95\% confidence interval) at set time intervals for different concentrations $(\mathrm{O}=0 \% ; \square=0.1 \%$; $\diamond=0.2 \%)$ of Xanthan gum (repeated measures ANOVA $\left.\left(F_{(12,60)}=5.45 ; \quad P=0.001\right)\right)$. Data points indicated with the same lettering are not significantly different.

was obtained at $60 \% \mathrm{RH}$, but at $80 \% \mathrm{RH}$ the same formulation significantly increased mortality. The addition of Zeba ${ }^{\circledR}$ to suspensions of S. yirgalemense increased mortality significantly at $60 \%$ and $80 \% \mathrm{RH}$. De Waal et al. (2013) tested Zeba ${ }^{\circledR}$ to improve control of diapausing codling moth, Cydia pomonella (Linnaeus) in tree trunk bioassays with $H$. zealandica, showing Zeba ${ }^{\circledR}$ to increase mortality significantly at both $60 \%$ and $80 \%$ RH.

Citrus leaves and fruit have a waxy cuticle and, therefore, the ability of nematode suspensions to stick to their surfaces is greatly impaired. The possibility of using the surfactant Nu-Film- $\mathrm{P}^{\circledR}$, and the polymer product Zeba ${ }^{\circledR}$, to stick IJs to leaf surfaces showed that the individual addition of Nu-Film- $\mathrm{P}^{\circledR}$ and Zeba ${ }^{\circledR}$ had no significant effect. However, a significant increase was obtained when using the combination of the two adjuvants. Although nematodes will move to the same protected habitats as those occupied by $P$. citri, the additions of such adjuvants would not only increase their numbers on the leaves, but also protect them against desiccation on the exposed leaf area, which would be advantageous to movement and survival of the nematodes.

In an aqueous suspension, nematodes quickly settle to the bottom of spray tanks, causing uneven distribution. Sedimentation time is an important factor to consider when nematodes are applied through an irrigation system, especially when deciding if larger nematodes can be used. The polymer products Zeba ${ }^{8}$ and Xanthan gum were evaluated at various concentrations for their ability to retard sedimentation of IJs. Xanthan gum was not evaluated at the highest concentration of $0.3 \%$, as the suspension became too thick to pass through spray nodules, making its use impractical. Heterorhabditis zealandica was used in the sedimentation experiment, because IJs of this species have an average length of $685 \mu \mathrm{m}$ and are larger than those of S. yirgalemense, with an average length of $635 \mu \mathrm{m}$ (Nguyen, 2007). Results of the sedimentation trial showed $H$. zealandica to settle quickly to the bottom of 25-ml measuring cylinders with only $9 \pm 2.4 \%$ of the initial nematode number recorded at a depth of $2 \mathrm{~cm}, 5 \mathrm{~min}$ after stirring. None of the Zeba ${ }^{\circledR}$ concentrations tested were able to retard sedimentation significantly after $1 \mathrm{~h}$. Only the $0.3 \%$ Zeba ${ }^{\circledR}$ formulation was able to retard sedimentation significantly after $30 \mathrm{~min}$, with $71 \pm 1.2 \%$ of the initial nematode number recorded. Nematode suspensions containing Xanthan gum were able to retard sedimentation significantly at both concentration levels, tested after $1 \mathrm{~h}$ sedimentation. The above-mentioned results are similar to those obtained by Schroer et al. (2005), which showed Xanthan gum $(0.1$ and $0.2 \%)$ to retard sedimentation of S. carpocapsae. Results also showed $S$. carpocapsae to settle quickly in water, with $50 \%$ and $10 \%$ of the initial nematode number recorded at a depth of $2 \mathrm{~cm}$ after $5 \mathrm{~min}$ and $1 \mathrm{~h}$ of sedimentation, respectively. IJs of $S$. carpocapsae are of length $558 \mu \mathrm{m}$ and would settle much more slowly than the larger IJs (685 $\mu \mathrm{m}$ length) of $H$. zealandica (Nguyen, 2007), with 9 and $0 \%$ of the initial nematode number being recorded for $H$. zealandica after $5 \mathrm{~min}$ and $1 \mathrm{~h}$, respectively.

The cryptic life style of $P$. citri and their ability to develop resistance to pesticides necessitates research towards alternative control methods. EPNs, which are lethal pathogens with a wide host range, are considered as a valuable biological control method for a variety of insect pest species. The results from a previous study (Van Niekerk \& Malan, 2012) stressed the need to improve nematode application formulations in order to increase control of $P$. citri under variable environmental conditions. In the current study, suboptimal conditions for nematode infection, with regard to nematode concentration and humidity, were maintained to simulate field conditions.

This investigation has shown that the addition of $0.3 \%$ Zeba ${ }^{\circledR}$ increased mealybug mortality in bioassays at $60 \%$ and $80 \%$ RH by retarding desiccation, extending nematode survival and improving mobility. Furthermore, the combined addition of both Nu-Film-P ${ }^{\circledR}$ and Zeba ${ }^{\circledR}$ increased application deposits on leaf surfaces, reducing the loss of nematodes by runoff. The same adjuvant to nematode suspensions effectively hindered their sedimentation, resulting in a more even distribution. To further determine the ability of such adjuvants to improve the control of $P$. citri on citrus by nematodes, they should be tested under glasshouse and field conditions. Further improvement of nematode application formulations, aimed at the control of aboveground citrus pests, should be done by testing different surfactant and polymer combinations. The application of nematodes to control above-ground pests on a commercial scale is a relatively new field of study and there is much room for improvement of application techniques and technology.

\section{Acknowledgements}

The authors would like to thank Daan Nel and Ken Pringle for assistance with statistical analysis. 


\section{Financial support}

The authors would also like to thank Citrus Research International (CRI), the National Research Foundation of South Africa (NRF-THRIP TP2011060100026) and the Citrus Academy for funding of the project.

\section{Conflict of interest}

None.

\section{References}

Abbott, W.S. (1925) A method of computing the effectiveness of an insecticide. Journal of Economic Entomolology 18, 265-267.

Bartlett, B.R. \& Lloyed, D.C. (1958) Mealybugs attacking citrus in California - a survey of their natural enemies and the release of new parasites and predators. Journal of Economic Entomolology 52, 90-93.

Blumberg, D. \& Van Driesche, R.G. (2001) Encapsulation rates of three encyrtid parasitoids by three mealybug species (Homoptera: Pseudococcidae) found commonly as pests in commercial greenhouses. Biological Control 22, 191-199.

Blumberg, D., Klein, M. \& Mendel, Z. (1995) Response by encapsulation of four mealybug species (Homoptera, Pseudococcidae) to parasitisation by Anagyrus pseudococci. Phytoparasitica 23, 157-163.

De Waal, J.Y., Malan, A.P. \& Addison, M.F. (2013) A superabsorbent polymer formulation for improved efficacy of Heterorhabditis zealandica (Rhabditida: Heterorhabditidae) control of codling moth larvae, Cydia pomonella (L.) (Lepidoptera: Tortricidae). Biocontrol Science and Technology 23, 62-78.

Efron, B. \& Tibshirani, R. (1993) An introduction to the bootstrap. 436 pp. Boca Raton, CRC.

Franco, J., Suma, P., Da Silva, E., Blumberg, D. \& Mendel, Z. (2004) Management strategies of mealybug pests of citrus in mediterranean countries. Phytoparasitica 32, 507-522.

Gaugler, R. \& Boush, G.M. (1978) Effects of ultraviolet radiation and sunlight on the entomopathogenic nematode, Neoaplectana carpocapsae. Journal of Invertebrate Patholology 32, 291-296.

Gaugler, R. \& Boush, G.M. (1979) Nonsusceptibility of rats to the entomogenous nematode Neoaplectana carpocapsae. Environmental Entomolology 8, 656-660.

Gaugler, R., Bednarek, A. \& Campbell, J.F. (1992) Ultraviolet inactivation of heterorhabditid and steinernematid nematodes. Journal of Invertebrate Pathology 59, 155-160.

Grewal, P., Ehlers, R.-U. \& Shapiro-Ilan, D.I. (2005) Nematodes as biological control agents. Wallingford, UK, CAB International.

Gullan, P.J. (2000) Identification of the immature instars of mealybugs (Hemiptera: Pseudococcidae) found on citrus in Australia. Australian Journal of Entomolology 39, 160-166.

Hattingh, V. (1993) Mealybugs and cottony cushion scale on citrus in Southern Africa. Citrus Journal 3, 20-22.
Hattingh, V. \& Moore, S.D. (2003) Mealybugs. pp. 65-69 in Grout, T.G. (Ed.) Integrated production guidelines for export citrus. Integrated Pest and Disease Management. Nelspruit, CRI.

Hattingh, V. \& Tate, B.A. (1995) Effects of field-weathered residues of insect growth regulators on some Coccinellidae (Coleoptera) of economic importance as biological control agents. Bulletin of Entomological Research 85, 489-493.

Hattingh, V. \& Tate, B.A. (1996) The pest status of mealybugs on citrus in Southern Africa. Proceedings of the International Society of Citriculture 1, 560-563.

Hattingh, V., Cilliers, C.J. \& Bedford, E.C.G. (1998) Citrus mealybugs. pp. 112-120 in Bedford, E.C.G., Van den Berg, M.A. \& De Villiers, E.A. (Eds) Citrus pests in the Republic of South Africa. Nelspruit, ARC-Institute for Tropical and Subtropical Crops.

Kaya, H.K. \& Stock, S.P. (1997) Techniques in insect nematology. pp. 281-301 in Lacey, L.A. (Ed.) Manual of techniques in insect pathology. London, Academic Press.

Lacey, L.A., Neven, L.G., Headrick, H. \& Fritts, R.J. (2005) Factors affecting entomopathogenic nematodes (Steinernematidae) for control of overwintering codling moth (Lepidoptera: Tortricidae) in fruit bins. Journal of Economic Entomology 6, 1863-1869.

Mahfoudhi, N.D. \& Dhouibi, M.H. (2009) Survey of mealybugs (Hemiptera: Pseudococcidae) and their natural enemies in Tunisian vineyards. African Entomolology 17, 154-160.

Malan, A.P., Nguyen, K.B. \& Addison, M.F. (2006) Entomopathogenic nematodes (Heterorhabditidae and Steinernematidae) from the southwestern parts of South Africa. African Plant Protection 12, 65-69.

Malan, A.P., Knoetze, A.P. \& Moore, S.D. (2011) Isolation and identification of entomopathogenic nematodes from citrus orchards and their biocontrol potential against false codling moth. Journal of Invertebrate Pathology 108, 115-125.

Michelakis, S. \& Hamid, H.A. (1995) Integrated control methods of the citrus mealybug, Planococcus citri (Risso) in Crete, Greece. Israel Journal of Entomolology 29, 277-284.

Mráček, Z. (2002) Use of entomoparasitic nematodes (EPANS) in biological control. pp. 235-264 in Upadhyay, R.K. (Ed.) Advances in microbial control of insects. New York, Kluwer Academic, Plenum Publishers.

Navon, A. \& Ascher, K.R.S. (2000) Bioassays of entomopathogenic microbes and nematodes. Wallingford, UK, CABI.

Nguyen, K.B. (2007) Methodology, morphology and identification. pp. 59-119 in Nguyen, K.B. \& Hunt, D.J. (Eds) Nematology monographs and perspectives, Vol. 5, Entomopathogenic nematodes: Systematics, phylogeny and bacterial symbionts. Leiden, The Netherlands, Koninklijke Brill NV.

Pieterse, W., Muller, D.L. \& Jansen van Vuuren, B. (2010) A molecular identification approach for five species of mealybug (Hemiptera: Pseudococcidae) on citrus fruit exported from South Africa. African Entomolology 18, 23-28.

Schroer, S. \& Ehlers, R.-U. (2005) Foliar application of the entomopathogenic nematode Steinernema carpocapsae 
for biological control of diamondback moth larvae (Plutella xylostella). Biological Control 33, 81-86.

Schroer, S., Ziermann, D. \& Ehlers, R.-U. (2005) Mode of action of a surfactant-polymer formulation to support performance of the entomopathogenic nematode Steinernema carpocapsae for control of diamondback moth larvae (Plutella xylostella). Biocontrol Science and Technolology 15, 601-613.

Smith, D., Beattie, G.A.C. \& Broadle, R. (1997) Citrus pests and their natural enemies: Integrated Pest Management in Australia. Queensland Department of Primary Industries, Queensland, Australia.

Tomalak, M., Piggott, S. \& Jagdale, G.B. (2005) Glasshouse applications. pp. 147-166 in Grewal, P.S., Ehlers, R.-U. \& Shapiro-Ilan, D.I. (Eds) Nematodes as biocontrol agents. Wallingford, UK, CAB International.

Unruh, T.R. \& Lacey, L.A. (2001) Control of codling moth, Cydia pomonella (Lepidoptera: Tortricidae), with Steinernema carpocapsae: Effects of supplemental wetting and pupation site on infection rate. Biological Control 20, 48-56.
Van Niekerk, S. \& Malan, A.P. (2012) Potential of South African entomopathogenic nematodes (Heterorhabditidae and Steinernematidae) for control of the citrus mealybug, Planococcus citri (Pseudococcidae). Journal of Invertebrate Pathology 111, 166-176.

Wakgari, W.M. \& Giliomee, J.H. (2003) The biology of three mealybug species (Hemiptera: Pseudococcidae) found on citrus in the Western Cape Province, South Africa. African Entomology 11, 173-182.

Wakgari, W.M. \& Giliomee, J.H. (2005) Description of adult and immature females of six mealybug species (Hemiptera: Pseudococcidae) found on citrus in South Africa. African Entomology 13, 281-332.

Winston, P.W. \& Bates, D.H. (1960) Saturated solutions for the control of humidity in biological research. Ecology 41, 232-237.

Wright, D.J., Peters, A., Schroer, S. \& Fife, J.P. (2005) Application technology. pp. 91-106 in Grewal, P.S., Ehlers, R.-U. \& Shapiro-Ilan, D.I. (Eds) Nematodes as biocontrol agents. Wallingford, UK, CAB International. 